\title{
Mikropoetyka i jej konteksty
}

\section{Elżbieta Winiecka}

Współczesne polemiki wokół autonomii i funkcji literatury koncentrują się - w dużym uproszczeniu, rzecz jasna - między dwoma stanowiskami odmiennie definiującymi przede wszystkim jej status i rolę. Pierwsze $\mathrm{z}$ nich wskazuje na uwikłanie literatury w rozmaite życiowe (społeczne, polityczne, obyczajowe, etyczne, medialne) problemy, które każde dzieło symbolicznie reprezentuje i rozgrywa, wywierając realny wpływ na czytających i ich postawy. Walory artystyczne utworu często schodzą przy tym na odległy plan, podporządkowane innym, ważniejszym celom. Druga postawa, wielokrotnie modyfikowana przez kolejne dwudziestowieczne szkoły czytania, przeciwnie - eksponuje przede wszystkim suwerenność dzieła literackiego jako całości samodzielnej i niezależnej, którą czytać należy w porządku innych pokrewnych zagadnień: konwencji, procesów historycznoliterackich, wewnętrznych przekształceń i zależności, rzutujących na przemiany konkretnych zjawisk o charakterze literackim ${ }^{1}$. Dla tak nastawionych badaczy to literatura jest najważniejsza i wcale nie zależy im na tym, by przepaść między nią i jej społecznymi kontekstami zasypywać, lecz raczej - by eksponować jej odrębność i suwerenność wobec nich.

Dwie strony sporu stara się pogodzić Rita Felski², która łagodząc tę dość kategorycznie zarysowaną opozycję, rozsądnie proponuje budowanie pomostów między czytaniem eksponującym swoistość i hermetyzm reguł komunikacji literackiej jako odrębnej dziedziny sztuki, wymagającej wyspecjalizowanych kompetencji, oraz pragmatycznym, a nawet naiwnym czytaniem, które z literatury czerpie przede wszystkim przyjemności i różnorakie pożytki. Innymi słowy, idąc w poprzek podziałów, pokazuje, że ze stanowisk obu stron warto czerpać inspirację, nie przywiązując się jednak zanadto do żadnego z nich.

\footnotetext{
${ }^{1}$ Takie podejście reprezentuje dziś np. Terry Eagleton, który postuluje powrót do zapomnianych nieco zasad czytania literatury jako literatury właśnie. Por. T. Eagleton, Jak czytać literaturę?, Warszawa 2014.

${ }^{2}$ R. Felski, Literatura w użyciu, przeł. zespół pod red. E. Kraskowskiej i E. Rajewskiej, Poznań 2016.
} 
Badaczka przede wszystkim trzeźwo zauważa, że akademickie kryteria oceny literatury mają się nijak do tego, co robią z nią zwykli czytelnicy. Ci ostatni kierują się emocjami, są spontaniczni i często bezkrytyczni wobec lektur, używają też literatury jako dopełnienia własnego życia, pozwalając kształtować się czytanym utworom, dając się uwieść opowiadanym przez nią historiom, przeżywając niekiedy gwałtowne i skrajne emocje i wzruszenia, a czasem po prostu czerpiąc z niej wiedzę o sobie i życiu. Literaturoznawcy przeciwnie - w ramach swoich profesjonalnych zatrudnień starają się unaocznić odrębność literatury jako sztuki słowa, chłodnym okiem oceniając walory artystyczne utworu, zachowując przy tym nieufność i sceptycyzm wobec prawdy dzieła oraz własnych ustaleń. Badaczka surowo ocenia, że ironia jest chorobą badaczy humanistów, którzy lekturę krytyczną w duchu hermeneutyki podejrzeń traktują jako obowiązujący wzorzec metodologiczny. Przeciwstawienie sceptycyzmu i podejrzliwości lekturze ufnej i prostodusznej zdaniem Felski nie odzwierciedla jednak wcale lekturowych realiów, obfitujących w doświadczenia różnorodne i dużo subtelniejsze od zarysowanej tu opozycji. W związku z tym autorka formułuje własny projekt badań faktycznego zaangażowania w tekst, które przywróciłyby literaturoznawstwo życiu, a do uniwersyteckich bibliotek wpuściłyby świeży powiew spontaniczności i emocji: „(...) być może przyszła pora na przeciwstawienie się automatyzmowi naszego własnego oporu, na zaryzykowanie przyjęcia innych form zaangażowania estetycznego"3 - pisze Felski, przypominając dodatkowo, że dzisiejszy warsztat literaturoznawcy ulokowany jest nie w zaciszu biblioteki, lecz wśród innych, dużo bardziej ekspansywnych i atrakcyjnych percepcyjnie mediów, z którymi literatura musi rywalizować o uwagę odbiorcy.

Jeśli literaturoznawstwo ma przetrwać XXI wiek, musi (...) odnowić swoje ambicje i metody poprzez nawiązanie więzi z innymi mediami, zamiast upierać się przy coraz mniej przekonujących tezach o swoim wyjątkowym statusie. Taka współpraca będzie oczywiście wymagała sumiennego zwrócenia uwagi na cechy form artystycznych specyficznych dla innych mediów ${ }^{4}$

- postuluje autorka. Chodzi jej przy tym zarówno o poszerzenie wrażliwości na inne niż językowe przekazy kultury, jak i o przyjęcie do wiadomości, że teoria nie zawsze wie więcej niż dzieło, że w związku z tym nie musi się sytuować o poziom świadomości wyżej od niego, a badacz powinien pogodzić się z tym, że sam w trakcie lektury może się czegoś dowiedzieć (choćby o samym sobie). Rita Felski proponuje zatem „fenomenologię hybrydową”, eksponującą w badaniach perspektywę pierwszoosobową i koncentrującą się w nich na sposobach wyłaniania się fenomenów. Postulując swoisty świadomy antyintelektualizm, somatyzację i uspontanicznienie odbioru, Felski wskazuje na konieczność przywrócenia profesjonalnej lekturze jej doświadczeniowego wymiaru. Praktyki czytania są bowiem wieloznaczne i nie podlegają prostym podziałom na te, które skupiają się na poetyce dzieła oraz jego walorach estetycznych i te, które stanowią formę ich użycia. W czytaniu chodzi raczej o ukazanie złożoności, nieprzejrzystości i problematyczności lektury i jej owoców. Konwencje, metody, powtarzalne procedury przeczą przyjemności czytania dla siebie. A o tę właśnie jednostkowość, subiektywizm i emocjonalizm estetycznej percepcji dzieła dopomina się Felski.

\footnotetext{
${ }^{3}$ Tamże, s. 120.

${ }^{4}$ Tamże, s. 30.
} 
Wskazuje więc na takie kategorie estetyczne, jak rozpoznanie, oczarowanie czy szok, których jej zdaniem doświadcza czytelnik zanim jeszcze zajmie pozycję krytycznego komentatora i badacza. To nowe bliskie czytanie jest swoistym przeciwieństwem close reading promującego lekturę immanentną, przenikliwą i analityczną, skoncentrowaną na tekście i jego znaczeniach. Propozycja opisu wybranych form zaangażowania, jakie wywołuje literackie dzieło, to próba spojrzenia nań nie jako na samoistny obiekt, lecz na fenomenologiczny byt, który staje się dopiero w świadomości czytającego. Stąd bierze się postulat „wysupływania poszczególnych włókien czytelniczej recepcji i umieszczania kolejno pod mikroskopem, aby dokładniej im się przyjrzeć”5. Ten sztuczny - podobnie zresztą jak tradycyjna analiza poetyki utworu - zabieg miałby jednak lepiej niż strategie tekstocentrycznego odbioru „uchwycić ziarno i fakturę codziennego doświadczenia estetycznego"6. Przekonanie o tym, że zrozumienie sposobów i przyczyn, dla których czytamy, przyczyni się do odnowienia literaturoznawstwa, a być może także do przywrócenia doświadczenia literackiego życiu, prowadzą badaczkę do sformułowania postulatu wypracowania swoiście rozumianej „mikroestetyki”, eksponującej afektywny i kognitywny wymiar czytania.

Jakkolwiek rozsądnie brzmi jej postulat tego nowego, bliskiego obcowania z dziełem, a także zasypywania podziałów między zwolennikami skrajnie odmiennych podejść do literatury, to jednak budzi on również wątpliwości. Jej krytyka świadomości i samoświadomości literaturoznawstwa, które negując proste przyjemności tekstu, zatruwają spontaniczną lekturę, a także sformułowany przez nią apel o zawieszenie ironicznej podejrzliwości wobec własnych metodologicznych procedur, brzmią w gruncie rzeczy dość nierealnie. Trudno bowiem wymazać liczącą sto lat historię teoretycznoliterackich zmagań, osadzonych zresztą na gruncie przemian filozofii świadomości i języka, tak jakby wątpliwości badaczy co do postaw uprawianej przez siebie dyscypliny były jedynie kaprysem znudzonych intelektualistów. A już całkiem niemożliwy wydaje się powrót do bezpośredniości lekturowego przeżycia, o której pisze Rita Felski.

Jeśli zatem odwołuję się do jej propozycji w kontekście rozważań o mikropoetyce, to dlatego, że daje tu znać o sobie charakterystyczny postulat coraz powszechniej dziś powtarzany i realizowany w pracach badaczy. Chodzi mianowicie o odejście od sztywnych reguł czytania na rzecz lektury zindywidualizowanej, mikroskopowej, niebojącej się przyznać do słabości literaturoznawczych metod, które w przeszłości przybierały nierzadko kształt metanarracji uzurpujących sobie już na wstępie lektury prawo do ustalenia, czym jest literatura i jakie są zadania krytycznego czytelnika. W obliczu dzisiejszych zawirowań humanistyki i literaturoznawstwa przyznanie się badacza do wyjściowej bezradności i nieuniknionego subiektywizmu wydaje się po prostu dużo bezpieczniejszym i uczciwszym punktem wyjścia do rozważań o literackich artefaktach. Postawa otwartości i uważności stanowi wstęp do każdej mikropoetologicznej lektury.

W świetle opisanych wyżej perypetii interesująco brzmi propozycja rewitalizacji uważnego czytania, proponowana przez tzw. śląską szkołę mikrologii literackiej . Wskazuje ona jeszcze

${ }^{5}$ Tamże, s. 145.

${ }^{6}$ Tamże.

${ }^{7}$ W ramach tego projektu ukazały się następujące publikacje: Miniatura i mikrologia literacka, t. 1, red.

A. Nawarecki, Katowice 2000; Miniatura i mikrologia literacka, t. 2, red. A. Nawarecki, Katowice 2001; Miniatura i mikrologia literacka, t. 3, red. A Nawarecki, B. Mytych-Forajter, Katowice 2003; Skala mikro w badaniach literackich, red. A. Nawarecki, M. Bogdanowska, Katowice 2005. W podobnym duchu pisana jest też książka: A. Nawarecki, Parafernalia, Katowice 2014. 
inną ścieżkę wyjścia z impasu, w którym znalazły się współcześnie badania literackie uwikłane w kulturowe, społeczne i polityczne konteksty. Jest to ścieżka pozornie przynajmniej prowadząca na stare szlaki - nawołująca do lektury uważnej i dociekliwej, do dbałości o analityczny szczegół, do wsłuchiwania się w melodię frazy, w rytm wersu i brzmienie aliteracji, a przy okazji do zwrócenia większej uwagi na sensualny, somatyczny wymiar lektury. To stara szkoła uważnego czytania, która jednakże, osadzona w nowym teoretycznym i kulturowym kontekście, prowadzić może do nowych odkryć i rewelatorskich niekiedy konkluzji. Pozwala ona na odsłonięcie tego, co podskórne (podtekstowe), co częstokroć w odbiorze tłumione było przez dominujący dyskurs. Te odkrywane w trakcie drobiazgowej lektury niuanse to niekiedy świadomie zacierane przez autora tropy, a czasem celowo zostawiane, ledwie dające o sobie znać poszlaki, które tylko najbardziej czujny czytelnik-detektyw jest w stanie połączyć w logiczną sieć związków i zależności ${ }^{8}$.

"Co to jest mikrologia?” - zadaje sam sobie pytanie Aleksander Nawarecki w artykule wstępnym do zbioru rozpraw Skala mikro $w$ badaniach literackich ${ }^{9}$. Jako pomysłodawca nowej nazwy dla, jak się zdaje, wcale nienowej postawy wobec literatury, autor precyzyjnie wskazuje problemy wiążące się ze zdefiniowaniem jej właściwości, zasięgu i specyfiki. Najogólniej ową mikrologiczną i mikropoetologiczną krzątaninę, którą w zdeklarowany sposób uprawiają polscy badacze od około dwudziestu lat, można określić jako wyróżniające się poznawczą pasją i dociekliwością, a zarazem świadome swych ograniczeń i podejrzliwe wobec przyjętych założeń przyglądanie się literackim drobinom. Lecz przecież, gdyby pominąć umowną, historycznie usytuowaną, nazwę tej postawy, okaże się, że to, co tutaj nas zajmuje, jest stałą składową warsztatu filologa, który od starożytności, czyli właściwie od zawsze, pochylał się z uwagą nad każdym detalem dostrzeżonym w tekście, dociekając jego rangi i znaczenia na wszystkie dostępne mu sposoby. Wie o tym zresztą doskonale Nawarecki, który próbując wyjaśnić nieprzekonanym wagę i funkcję mikrologii, odwołuje się do rozmaitych badawczych szkół, wskazując, że podejście mikrologiczne nie jest zarezerwowane dla wybranych ani wyłącznie współczesnych sposobów czytania. Przeciwnie. Mikropoetyka stanowi właściwy żywioł filologii; to tutaj ujawnia się jej finezja, precyzja i rola w odsłanianiu tego, co w potocznym, codziennym patrzeniu, czytaniu i rozumieniu zwyczajnie umyka uwadze. Na tym też polega chyba jej fenomen i tu kryje się jej szansa: mikrologia łączy w obrębie swych dociekań przedstawicieli różnych szkół i poglądów, co doskonale widać w publikacjach przygotowanych dotychczas przez katowickich badaczy.

Nie tylko nie istnieje jedna, koherentna definicja mikrologii, ale też w projektowane przez nią postępowanie z tekstem wpisana jest niemożność ustalenia jasnych reguł, powtarzalnych zasad, czy ustalonych raz na zawsze założeń, które umożliwiłyby uspójnienie i uporządkowanie sposobu postępowania jej adeptów z przedmiotem badań. Sam ów przedmiot wymaga zresztą osobnej

\footnotetext{
${ }^{8}$ Dobry przykład efektywności tego typu badań, prowadzonych niezależnie od propozycji katowickich teoretyków, stanowi książka Agnieszki Gajewskiej Zagłada i gwiazdy. Przeszłość w prozie Stanisława Lema (Poznań 2016). Poznańska badaczka dzięki swej niezwykłej metodzie mikrolektury napisała nowy, pod wieloma względami rewolucyjny, rozdział lemologii. Uważne, skoncentrowane na analizie literackich tekstów i historycznych źródeł, osadzone w biograficznych i historycznoliterackich kontekstach czytanie poparte zostało w tym przypadku feministyczną z ducha wrażliwością i wyczuleniem na to, co nieoczywiste, niekiedy zaś po prostu przemilczane. Dzięki tej metodzie autorce udało się prześledzić obecność w prozie Lema nieomal nieuchwytnych ech traumy Zagłady, która w dotychczasowych badaniach nad twórczością tego pisarza była bądź całkowicie przemilczana, bądź bagatelizowana.

${ }^{9}$ A. Nawarecki, Czarna mikrologia, [w:] Skala mikro w badaniach literackich, s. 9.
} 
uwagi: czy jest nim pojedynczy tekst? Gatunek literacki? Fraza? Słowo? A może cały dorobek autora? Wydaje się, że każdorazowo zależy to od wstępnych (subiektywnych!) założeń przyjętych przez badacza. Ważna jest tu bowiem perspektywa porównawcza, która eksponuje różnice skali, pozwalając unaocznić ten fundamentalny fakt, że małe jest małe w porównaniu z tym, co wielkie (lub też, w zależności od potrzeb: oficjalne, dominujące, jawne, samo przez się zrozumiałe, ważne, inspirujące). I że to, co do tej pory bywało pomijane lub jedynie przelotnie wskazywane, zwłaszcza w panoramicznej perspektywie historii literatury, znajduje się dziś w centrum zainteresowania interpretatorów. Jak widać, skala mikro jest mikro tylko wtedy, gdy w naszej świadomości istnieje dla niej szersze tło: makroproblemów, makroprocesów, makrostruktur.

Choć zatem mikrologia podsuwa więcej pytań niż dostarcza pewników, jest ona takim sposobem uprawiania refleksji humanistycznej, który współcześnie ma szansę stać się szczególnie cenny i pożyteczny. Na potwierdzenie własnych mikrologicznych intuicji, a zarazem w celu rozwiania wątpliwości tych, którzy nie do końca wierzą w potencjał poznawczych możliwości mikrologii, Nawarecki przywołał definicję sporządzoną na początku XXI wieku przez Przemysława Czaplińskiego. Poznański krytyk, z Borgesowską z ducha i metody, maestrią symuluje istnienie encyklopedycznego hasła, mającego uprawomocnić zarówno zjawisko, jak i przedmiot jego badań. Na czwartej stronie okładki jego Mikrologów ze śmierciq mieści się taki oto wypis:

mikrolog <gr. mikrós+lógos=mały+słowo, nauka, pojęcie, prawda> 1. hum. interpretator drobin, badacz rzeczy małych; 2. gr. mowa mniejsza (lógos mikrón), termin w retoryce antycznej określający mowy przygodne, wygłaszane do przypadkowych słuchaczy, domowników, przedmiotów bądź siebie samego, kompozycyjnie i stylistycznie nieprzewidywalne, dotyczące spraw jednostkowych, służące wyrażeniu uczuć i myśli intymnych, stanowiące także sposób uprawiania refleksji niesystemowej - do tradycji mowy mniejszej sięgał dialog sokratejski, solilokwium, monolog, fragment; 3. ant. ułomna, niepełna rozmowa (mikron logos), dialog z milczącym adresatem, uobecnianym poprzez wypowiedzi prawdopodobne (zob. monolog wypowiedziany); 4. est. cząstka całości nie przyporządkowana określonemu miejscu i kompozycyjnie samodzielna (zob. prolog, epilog); 5. filoz. gr. mała prawda, niepewna prawidłowość formułowana na podstawie wydarzenia powtarzalnego, lecz każdorazowo przebiegającego odmiennie (zob. chaotyka); 6. gr. jednostkowe przeznaczenie, prywatne fatum (zob. logos); 7. dekonstr. samodzielna cząstka rozmowy składającej się z wielu wypowiedzi (zob. polilog) i prowadzonej w warunkach nieosiągalnego porozumienia, nastawiona na zdefiniowanie różnic i określenie ich statusu; 8. postmoder. mała narracja; 9. filoz. pot. mądrość codzienna, wyrastająca z czynności domowych, świadoma swoich ograniczeń i niewiedzy, znajdująca swoje przedłużenie w gadaniu, zdradzana przez uogólnienia i syntezy (zob. „Wiem, że nic nie wiem”, Miś o Małym Rozumku; krzątactwo ${ }^{10}$

Jakkolwiek wszystko w tej definicji jest prawdą, nic nie jest takie, jak zdaje się ona sugerować. Zjawiska, nazywane w niej, są bowiem efemeryczne i kruche, wymykające się jednoznacznemu określeniu i konkretyzacji. Stąd objaśnienia z okładki zarysowują raczej rozległe horyzonty mikrologicznej refleksji, aniżeli cokolwiek ujednoznaczniają. Czapliński na użytek własnych badań wyjaśnia, że tropione przez niego we współczesnej prozie mikrologi to „rozmowy z milczącym adresatem uobecnianym poprzez wypowiedzi prawdopodobne, małe narracje szukają-

${ }^{10}$ P. Czapliński, Mikrologi ze śmiercią. Motywy tanatyczne we wspótczesnej literaturze polskiej, Poznań 2001 [wypis z okładki]. 
ce jednostkowego przeznaczenia wyrażanego w języku idiomatycznym, niepewne prawidłowości formułowane na podstawie wydarzenia powtarzalnego, lecz każdorazowo przebiegającego odmiennie"11. Tak kształtuje się niepewny przedmiot prowadzonych przez niego obserwacji. Jeśli zaś chodzi o mikrologiczną perspektywę, przyjmowaną przez autora książki, przypomina ona raczej postawę nieufnego etnologa-odkrywcy, poznającego obcy ląd i stykającego się z niezrozumiałą dla niego innością jego mieszkańców, szukającego dopiero dla swych doświadczeń nowego języka, aniżeli pewnego swoich metod i celu naukowca, który w precyzyjnie zdefiniowanych warunkach laboratoryjnych obserwuje i opisuje niezmienny obiekt.

Mikrolog porusza się z poczuciem zawsze niedostatecznej kompetencji i niekompletności zgromadzonych danych, a w związku z tym nieustannie gotów jest podważyć stan swoich ustaleń. I to, w moim odczuciu, chyba najistotniejsza, filozoficzna zmiana, jaka pojawiła się w mikrologicznym podejściu do tekstu literackiego. To, co zawsze było cechą humanistyki jako sfery rozumienia, a nie wiedzy - nieautonomiczność jej podstaw i nieostateczność ustaleń - przybiera teraz kształt równoprawnego przedmiotu poznania. Oto dzięki pracy z tekstem i pracy tekstu interpretator dowiaduje się równie wiele o czytanym utworze, jak o sobie - o swoich ograniczeniach, predyspozycjach i możliwościach.

Na potwierdzenie faktu, że podejście to ma swoją szacowną tradycję, Czapliński wymienia style interpretacji, których kontynuatorem lub dłużnikiem się czuje. Padają nazwiska i nazwy szkół, na które powołuje się też Nawarecki: fantazmatyka Marii Janion, hermeneutyka, amerykańska szkoła close reading, dekonstrukcjonizm, interpretacje Rolanda Barthes'a i jego koncepcja punctum, diagnozy postmodernistycznej kondycji kultury Jeana-François Lyotarda z jej kluczową tezą o kresie wielkich narracji, wreszcie „krzątactwo” Jolanty Brach-Czainy uprawiane w Szczelinach istnienia, a także poezja Czesława Miłosza i jego postawa „uważności” ${ }^{12}$.

Czapliński zwraca przy tym uwagę, że wszystkie te style lektury zachowują walor autorskich, niepowtarzalnych, jednorazowych, a tym, co je łączy, jest skupienie uwagi na drobiazgach. „Być może jest to osobną prawidłowością mikrologów, że nie nadają się do powtórzenia: w odróżnieniu od metod (czyli makrologii), są nieprzekazywalne”13. Mikrologia to zatem „czytanie drobin” ${ }^{14}$, ponieważ jednak oba człony tej definicji: czytanie i drobina nie są same przez się zrozumiałe, wachlarz możliwych sposobów obcowania z tekstami jest praktycznie niewyczerpywalny, a sama quasi-metoda jawi się jako eklektyczna, nieciągła i polimorficzna ${ }^{15}$. Zwłaszcza,

\footnotetext{
${ }^{11}$ Tamże, s. 10.

${ }^{12}$ Do listy tej za Nawareckim dodać można też „miniaturę” Gastona Bachelarda (Miniatura, przeł. K. Mokry, T. Markiewka, „Literatura na Świecie” 1999, nr 9, s. 153-187), teorię „mikrolektury” Jeana-Pierre'a Richarda(Microlectures I, Seuil, „Poétique” 1979, Microlectures II. Pages Paysages, Seuil, „Poétique”, 1984), „mikroskopię” Romana Jakobsona (Une microscopie du dernier „Spleen” dans les Fleur du mal, [w:] tegoż, Questions de poetique, Paris 1973.), a także pojawiające się w rozmaitych kontekstach neologizmy z cząstką mini- i mikro- u Bachtina, Benjamina, Foucaulta. Dodam tylko, że w artykule tym nie podejmuję tematu małych form i mikrogatunków literackich, które stanowią w moim odczuciu osobny problem i należy je raczej łączyć z autorską filozofią (a czasem „filozofiuchną") twórczości i egzystencji konkretnych poetów i pisarzy. Gdyby chcieć sporządzić listę twórców, doceniających „smak detalu”, lista byłaby bardzo długa. A może musiałaby po prostu zawierać nazwiska wszystkich artystów słowa? Tutaj interesuje nas jedyne mikropoetyka jako poetyka odbioru i sposób uprawiania literaturoznawczej refleksji.

${ }^{13}$ P. Czapliński, Mikrologi, s. 10.

${ }^{14}$ Tamże.

${ }^{15}$ Por. tamże, s. 10-11.
} 
jeśli weźmiemy pod uwagę, że interpretator nie jest bezstronnym obserwatorem, lecz częścią komunikacyjnej relacji, w którą wchodzi i którą współprojektuje.

Mikrologia chętnie odwołuje się też do sytuacji innych, niehumanistycznych dziedzin poznania, wskazując na to, że „moda na małe” ${ }^{16}$ nie jest wyłącznie projektem literaturoznawców, lecz symptomem szerszego zainteresowania skalą mikro, dotyczącego także nauk społecznych i przyrodniczych, takich jak: mikroekonomia, mikrosocjologia, mikrochirurgia czy mikrobiologia. Podobieństwa te ograniczają się częściowo do zbieżności wyłącznie leksykalnej, a analogie mają charakter odległych metonimii bądź metafor. Warto jednak zauważyć, że istotnie zarówno obserwowane procesy kulturowe, społeczne i psychologiczne, jak i wpływ rozwoju nowych technologii w medycynie i informatyce, można połączyć ze zmianą w poznawczym podejściu do wielu problemów. Większe zaufanie zyskują precyzyjne lub zindywidualizowane mikroanalizy, aniżeli odwołujące się do szerokich perspektyw diagnozy i uogólnienia.

Najciekawsze związki łączą mikrologię literacką z mikrohistorią. Jak pisze Ewa Domańska, ta metoda badań historiograficznych rozwijała się już od lat siedemdziesiątych XX wieku jako „odpowiedź na kryzys tradycyjnego rozumienia historii, który ujawnił się między innymi w zainteresowaniu «sekretnym wymiarem rzeczywistości» (Levinas), w zwrocie od makro do mikro, od zewnętrza do wnętrza, od historii jako procesu do historii jako ludzkiego doświadczenia" 17 .

Posługując się zaczerpniętą z antropologii interpretatywnej metodą "gęstego opisu"18 i skupiając się na studium pojedynczych przypadków (case studies), historycy z zachowaniem subiektywnej perspektywy narracji opisywać zaczęli niewielkie obszary czasu i przestrzeni, pochylając się przede wszystkim nad tymi dziedzinami i sferami życia, które umykały uwadze tradycyjnej historii. To udokumentowane w tekstach życie codzienne, obyczaje, świadomość i przekonania ludzi, często zwykłych, nieobecnych dotychczas na kartach podręczników historii, stają się domeną dociekań mikrohistoriografów, zdających sobie sprawę, że przeszłość utkana jest z niezliczonej liczby indywidualnych losów, które stanowią podglebie i faktyczne środowisko, a także warunek wielkich wydarzeń i dziejowych procesów.

Codzienność, do tej pory uważana za przezroczyste tło wydarzeń, staje się też przedmiotem zainteresowania antropologów kultury i literaturoznawców. Zostaje wynaleziona na nowo ${ }^{19}$. Oficjalnym, nadzorowanym przez instytucje władzy strategiom działania oraz wielkim historycznym narracjom przeciwstawione zostają codzienne taktyki: prywatne sposoby radzenia sobie zwykłych ludzi z narzucanymi im odgórnie wzorcami życia, myślenia, czytania:

Historycy skupili się na badaniach małych społeczności i konkretnych jednostek w celu osiągnięcia zarówno maksymalnej głębi w oglądzie przeszłej rzeczywistości, jak i jej większego kolorytu

\footnotetext{
${ }^{16}$ Por. E. Suszek, Moda na małe? Innowacyjność śląskiej mikrologii literackiej, „Postscriptum Polonistyczne” 2016, nr 1(17), s. 179-191.

${ }^{17}$ E. Domańska, Mikrohistorie. Spotkania w międzyświatach, wyd. 2 uzup. i uaktualnione, Poznań 2005, s. $270-271$.

${ }^{18}$ Por. C. Geertz, Opis gęsty w poszukiwaniu interpretatywnej teorii kultury, [w:] tegoż, Interpretacja kultur. Wybrane eseje, przeł. M. Piechaczek, Kraków 2005.

${ }^{19}$ Por. M. de Certeau, Wynaleźć codzienność. Sztuki działania, przeł. K. Thiel-Jańczuk, Kraków 2008; M. de Certeau (współautorzy: L. Giard, P. Mayol), Wynaleźć codzienność 2, Mieszkać, gotować, przeł. K. Thiel-Jańczuk, Kraków 2011.
} 
i naturalności. Mikrohistoria jest w swych intencjach jakościowa i miniaturowa, a nie ilościowa i globalizująca ${ }^{20}$.

Podobne podejście cechuje mikrologię literacką, która - najpierw w fazie krytycznej dekonstrukcji racjonalnych podstaw i założeń interpretacji tekstów, zjawisk i procesów, a potem w postaci niezliczonych innych sposobów uprawiania lektury subiektywnej, krytycznej wobec swego przedmiotu, nieoczywistej, uważnej, a zarazem subwersywnej, reprezentowanej przez style czytania zwolenników różnych szkół hermeneutyki, psychoanalizy, krytyczek feministycznych, badaczy gender studies i queer theory, studiów postkolonialnych i wielu innych, odsłaniała w tekstach to, co wydawało się dotychczas nie dość istotne, marginalne, niezrozumiałe, a nawet niezauważalne.

W horyzoncie problematyki mikroskali mieści się też mikrofizyka, zazwyczaj lokowana na biegunie przeciwnym do zainteresowań humanistyki. O dziwo jednak, jeśli uważnie przyjrzeć się teoretycznym założeniom oraz konsekwencjom, jakie odkrycia tej nauki przyniosły, może okazać się, że i ona wywiera znaczny, choć niebezpośredni wpływ na epistemologiczne warunki pracy współczesnego mikrologa, który porusza się w świecie chwiejnym, niestabilnym i nieuchwytnym. Mikrofizyka to bowiem fizyka atomów i cząstek elementarnych ${ }^{21}$. Jej ojcem był Niels Bohr, który w 1913 roku przedstawił swój model atomu. Rewolucyjne odkrycie, że elektron może przemieszczać się w atomie z orbity na orbitę, emitując lub wchłaniając przy tym kwant światła (foton) zainicjowało rozwój mechaniki kwantowej. To dzięki niej świat i jego wizja, badane i opisywane przez klasyczną fizykę, odeszły w przeszłość. Od ponad dziewięćdziesięciu lat, czyli od momentu swych narodzin, mechanika kwantowa, a wraz z nią współczesna teoria nauki, rozwijają się, opierając się na zasadzie nieoznaczoności, sformułowanej w 1926 roku przez ucznia Bohra - Wernera Heisenberga. Zasada ta odnosi się do właściwości mikrocząstek - obdarzonych podwójną, korpuskularno-falową naturą odpowiedników drobin, które tak frapują miłośników małego w literaturoznawstwie - i wskazuje, że im dokładniej mierzy się prędkość cząstki, tym mniej dokładniej da się określić jej położenie, i odwrotnie. Nie sposób więc przekroczyć granicy dokładności pomiaru, która nie zależy ani od rodzaju cząstki, ani od zastosowanej w badaniach metody. Nieusuwalna niemożność precyzyjnego określenia aktualnego stanu obserwowanego obiektu sprawiła, że mechanika kwantowa, zamiast określać konkretny wynik pomiaru, skupia się na wskazaniu zbioru możliwych wyników i określeniu prawdopodobieństwa zaistnienia każdego z nich. Teoria nauki opisuje nie tyle rzeczywiste stany świata, co pewne właściwości tego, co w danej sytuacji poddawane jest obserwacji. Zasada nieoznaczoności wpłynęła również na wyobrażenia o makroświecie. Okazała się konstytutywną jego cechą i zmieniła radykalnie sposób rozumienia i wyjaśniania zjawisk. Do nauki, będącej wcześniej domeną praw pewnych i stałych, wkroczyła przypadkowość i nieprzewidywalność.

\footnotetext{
${ }^{20}$ E. Domańska, Mikrohistorie..., s. 273.

${ }^{21}$ Kolejną część rozważań opieram na wiedzy ogólnej (mikroskopijnej w rozumieniu rozmiaru, nie szczegółowości), na czytanych w różnym czasie opracowaniach popularnonaukowych, a przede wszystkim na lekturze książek: Abrahama Paisa: Czas Nielsa Bohra. W fizyce, filozofii i polityce, przeł. P. Amsterdamski, Warszawa 2006 oraz Richarda P. Feynmana, QED - osobliwa teoria światła i materii, przeł. H. Białkowska, 2001 i wybranych fragmentów podręcznika Richarda P. Feynmana, Roberta B. Leightona, Matthew Sandsa, Feynmana wykłady z fizyki, t. 3, Mechanika kwantowa, wyd. 4, Warszawa 2004.
} 
„Mechanika kwantowa w dużej mierze opiera się na zjawiskach sprzecznych z naszą intuicją, przeczących całej naszej wiedzy opierającej się na świecie makro" ${ }^{22}$ - zauważa recenzent $\mathrm{Me}$ chaniki kwantowej. Teoretycznego minimum. Słynny eksperyment myślowy Erwina Schrödingera $z$ kotem zamkniętym w szczelnym pudełku z jednym atomem, który wskutek swego rozpadu uruchomić miałby działanie trucizny, wskazuje jednak, że trudno określić granicę między światem mikro- i makroskopowym, w którym zjawisko superpozycji cząstek (czyli zajmowania przez nie dwóch pozycji lub przyjmowania dwóch stanów równocześnie) nie jest już możliwe. Zgodnie z mechaniką kwantową, mówiącą, że cząstki mają zdolność do znajdowania się w superpozycji wyłącznie w środowisku pozbawionym obserwatora, kot Schrödingera powinien być jednocześnie żywy i martwy. Dlaczego zatem nie jest? Wyjaśnienia znacząco przekraczają zarówno zakres autorskich kompetencji, jak i potrzeb w prowadzonym tu wywodzie. Niemniej owa sprzeczność między tym, co podpowiadają nam doświadczenie i zdrowy rozsądek, a tym, czego dowiadujemy się dzięki ustaleniom fizyków-mikrologów, stanowi rodzaj mocnego, bo pochodzącego $\mathrm{z}$ nauk doświadczalnych, uzasadnienia dla współczesnego statusu nauk humanistycznych, w tym literaturoznawstwa. Mikropoetyka ma swoją rolę do odegrania, jeśli uznamy, że nie chodzi tylko o skalę przedmiotu badań i idące za zainteresowaniem tym, co małe, docenienie i wyróżnienie drobiazgu, detalu interpretacyjnego, błahostki, ale o postawę epistemologiczną, eksponującą autorefleksję, dociekliwość, wnikliwość, podejrzliwość i świadomość sytuacyjności (uzależnienia od rozmaitych uwarunkowań) pozycji badacza, właściwą także naukom ścisłym.

Niepozorne badania mikropoetologiczne prowadzą więc do rozsadzenia dotychczasowych ram i makroporządków literackich, które zwykliśmy uważać za oczywiste. Mikrologiczne lektury podważają ustalone prawdy dotyczące konkretnych tekstów, natury ich rozumienia i roli, jaką odgrywają w makroprocesach. Doceniając bliskość oglądu, mikrologia zawierza równocześnie, zgodnie z charakterystyką Aleksandry Kunce, „wszelkim rozproszeniom, rozbiegom myśli, mikrobłądzeniu w nadziei na doszukanie się uwikłań myśli w to, co jednocześnie stałe i zmienne, całościowe i fragmentaryczne, ciągłe i punktowe etc." ${ }^{23}$.

Warto nadmienić, że to właśnie dzięki poznaniu zasad mechaniki kwantowej możliwy był rozwój współczesnej energetyki jądrowej i elektroniki, w tym wynalezienie urządzeń elektronicznych: mikroprocesorów, tranzystorów, telewizorów, komputerów, laserów oraz mikroskopu elektronowego. Jeśli klasyczny mikroskop optyczny przyjąć za metonimię postawy uważności, to jest to uważność podmiotu Kartezjańsko-Kantowskiego, który próbuje zgłębić, a następnie uspójnić świat dzieła w granicach własnej świadomości. Tymczasem współczesne mikroskopy elektronowe, dające naukowcom dostęp do mikroświatów, w których mają do czynienia z wiązkami elektronów w próżni, każą zrewidować wyobrażenie mikrologicznej metody jako gwarancji precyzji i dociekliwości poznawczej, odsyłając do założeń probabilistycznych, sprzecznych z Newtonowską wizją świata.

\footnotetext{
${ }^{22}$ R. Kosarzycki, recenzja: Mechanika kwantowa. Teoretyczne minimum - Leonard Susskind, Art Friedeman, <http://www.pulskosmosu.pl/2016/05/24/recenzja-mechanika-kwantowa-teoretyczne-minimum-leonardsusskind-art-friedeman/> [dostęp: 9.02.2016]

${ }^{23}$ A. Kunce, O motylu i dyskretnym uroku mikrologii, [w:] Skala mikro w badaniach literackich, s. 39 [podkreślenia A.K].
} 
Na koniec tego wątku naszych mikrorefleksji zauważmy, że współczesne literaturoznawstwo - podobnie jak fizyka - konstruuje sobie przedmiot swoich badań i wszystko, co na jego temat możemy powiedzieć, odnosi się do wyobrażeń, jakie budujemy na podstawie przyjętych założeń. Ma charakter przybliżeń, a nie prawd na temat natury swego przedmiotu. Mikropoetyka, pozbawiając interpretatora nadziei na znalezienie oparcia dla własnych ustaleń w czymś, czego nie dałoby się zakwestionować, budzi z jednej strony swoisty lęk przed utratą legitymizacji, z drugiej jednak - inspiruje do wciąż nowego, odkrywczego czytania dzieł już dobrze znanych.

Ta szczególna właściwość badań mikropoetologicznych zmusza więc badacza do zachowania nieufności względem własnych ustaleń. Jako perspektywa widzenia ${ }^{24}$ nie może zachować jednolitości i ostateczności swych sądów. A przy tym każdy detal traktuje jako ślad obecności i wpływu makroświata, bo to, co najmniejsze, nie jest samoistne, lecz uwikłane w sieć rzeczywistych związków, skojarzeń i ledwie wyczuwalnych intuicji, które nie mieszczą się w systemowym myśleniu, a zarazem nie mogą się bez niego obejść:

W tym sensie mikrologia staje się strażniczką natury naszej myśli jako takiej - utkanej z braku koherencji, głębi i przyczynowości, ale również podszytej jednościowymi tendencjami i pragnieniem systemowości. Czy można nie myśleć mikrologicznie, jeśli chce się tropić podskórny rytm rzeczywistości [?] ${ }^{25}$

- retorycznie pyta jedna z komentatorek teorii mikrologicznej.

Mikropoetyka jako poetyka odbioru nie tylko podejmuje próbę redefinicji przedmiotu swoich badań, lecz przede wszystkim wymaga ponownego określenia układu, w którym odbywa się lektura. Należy jasno powiedzieć, że pozycja, jaką zajmuje badacz i sposób, w jaki definiuje swoją rolę, nie pozostają obojętne dla efektów analizy. Z kategorią mikropoetyki łączy się uważność, jaka powinna - co na pozór wydaje się oczywiste - cechować każdego interpretatora. Jednakże uwaga, którą poświęcamy określonym elementom rzeczywistości lub dzieła, nie jest kategorią neutralną ani uniwersalną. Przeciwnie - uzależniona jest od wielu czynników historycznych, mających wpływ na to, co znajduje się w polu naszej percepcji, oraz na to, dlaczego właśnie ten a nie inny element uznajemy za ważny, interesujący, frapujący, wart pogłębionej analizy. Jonathan Crary, zajmujący się historycznymi przemianami kategorii uważności, podkreśla:

Normatywne definicje uważności zrodziły się wprost ze zrozumienia, że pełne uchwycenie rzeczywistości nie jest możliwe i że ludzka percepcja, determinowana przez fizyczne i psychiczne procesy i własności, pozwala jedynie na prowizoryczne, zmieniające się przybliżenie swych przedmiotów ${ }^{26}$.

Model poznawczy, w którym to podmiot podtrzymuje spójność rozumienia świata, nie jest ani ściśle optyczny, ani tym bardziej zgodny z rzeczywistością. Cała linia filozofów podejmujących krytykę obecności: Jacques Derrida, Maurice Blanchot, Georges Bataille, Jacques Lacan

${ }^{24}$ Por. A. Kunce, O motylu..., s. 43.

${ }^{25}$ Tamże, s. 45 [podkreślenie A.K.].

${ }^{26} \mathrm{~J}$. Crary, Zawieszenia percepcji. Uwaga, spektakl i kultura nowoczesna, przeł. Ł. Zaremba, I. Kurz, red. nauk. i posł. I. Kurz, Warszawa 2009, s. 17. 
wskazuje na brak cechujący każde doświadczenie percepcyjne i związane z tym przekonanie o niemożliwości niezapośredniczonego zanurzenia w jakimkolwiek doświadczeniu. Świat nie prezentuje się bowiem patrzącemu bezpośrednio, a percepcja nie jest atemporalna. Dotyczy to zarówno codziennej uwagi, jaką poświęcamy rzeczom, osobom, zdarzeniom, które - mówiąc obrazowo - są przez nas każdorazowo wytwarzane, jak i - w jeszcze większym stopniu - tekstom kultury: lekturom, obrazom, filmom itd. Uwaga, z jaką kierujemy się ku wybranym przez nas (lub narzucanym nam) elementom, obnaża też swój własny sprzeczny status. $Z$ jednej strony wyostrzając przedmiot oglądu, $z$ drugiej przyczynia się do odsunięcia poza obręb percepcji innych elementów rzeczywistości, która rozmywa się i traci - dosłownie - na znaczeniu. $\mathrm{Na}$ tym polega podwójna natura percepcji, która zawsze coś musi stracić, aby zyskać: dostrzegając detal, gubi z oczu całość, a spoglądając na całość, nie widzi szczegółu.

Wskazując na etymologię słowa „uwaga” w języku angielskim, oznaczającego zarówno uważność (attantion), jak i stan oczekiwania i napięcia (tension), Crary koncentruje się na postawie podmiotu. Ten zaś, ulegając zachwytowi lub kontemplacji, „jednocześnie pozostaje unieruchomiony i oderwany od ziemi" ${ }^{27}$. Stan zawieszenia, zakłócenia, czy wręcz negacji percepcji towarzyszy więc najgłębszym doznaniom zanurzenia w czymś i zaabsorbowania. Dlatego do charakterystyki opisywanego przez Ritę Felski afektywnego zauroczenia i oczarowania czytelnika dziełem dodać możemy, że kiedy działa ono na niego w ten sposób, pozbawia go, przynajmniej na pewien czas, zdolności krytycznej. I jakkolwiek mamy tu do czynienia nie z dwiema wykluczającymi się postawami odbiorcy, lecz zaledwie z dwoma etapami percepcji dzieła, to jednak uznać trzeba chyba, że mikropoetyka skoncentrowana na dziele i mikroestetyka zainteresowana czytelniczym odbiorem dzieła projektują dwie odmienne perspektywy oglądu sytuacji komunikacyjnej, dwa różne obiekty badań.

Pouczające jest to, w jaki sposób Jonathan Crary rekonstruuje historyczność kategorii uwagi. Podążając drogą wytyczoną przed laty przez Waltera Benjamina, pokazuje, że jest ona nie tyle podmiotową predyspozycją, co kulturowym konstruktem, podlegającym wewnętrznym przekształceniom, ale też oddziaływaniom socjotechnicznym, wśród których niebagatelną rolę odgrywa kontekst technologiczny. To za sprawą technologicznych porządków kształtują się pewne „naturalne” predyspozycje podmiotu do utrzymywania uwagi, a także do natężenia aktywności refleksyjnej. Tego rodzaju nastawieniu sprzyjała technologia druku z jej najwyżej cenionym dokonaniem - kulturą literacką, formującą szczególny typ aktywności intelektualnej, którą zwykliśmy łączyć z hermeneutyczną dociekliwością. Współcześnie cechą dominujących technologii wizualnych (kina, komputera, Internetu) jest „narzucenie stałego poziomu niskoaktywnej uważności” ${ }^{28}$. To z kolei powoduje, że wiążące się ze stanem nieuwagi zamyślenie „dziś najczęściej wiąże się z zaprogramowanymi rytmami, obrazami, prędkościami i obwodami, które sprawiają, że wszystko, co nie odpowiada ich formatom, zostaje odrzucone lub uznane za nieistotne"29.

Co ciekawe, Aleksander Nawarecki na horyzoncie mikropoetologicznej refleksji literaturoznawczej wskazuje chaosmiczne rozsianie i rozmnożenie, które dziś wytwarza i reprezentuje in-

\footnotetext{
${ }^{27}$ Tamże, s. 21.

${ }^{28}$ Tamże, s. 108.

${ }^{29}$ Tamże, s. 110.
} 
ternetowa $\operatorname{sieć}^{30}$. Warto zastanowić się, na ile zjawiska literackie obecne w cyfrowej wirtualności spełniają wymogi mikrologii, a przede wszystkim - na ile poddają się regułom mikropoetologicznej lektury. Skala mikro, w której toczą się algorytmiczne procesy, konstytuujące powierzchnię widzialności w cyfrowych mediach, w żaden sposób nie daje się uzgodnić $\mathrm{z}$ regułami mikropoetyki jako strategii czytania nastawionej na zgłębianie i analizę detalu. Między językami matematyki używanymi do programowania a kodami audiowizualnymi, z jakimi mamy do czynienia na płaszczyźnie kulturowych interfejsów, nie ma związku wynikania i prawdopodobieństwa, który mógłby stać się przedmiotem mikrologicznej analizy i interpretacji. Literaturoznawcy brakuje nawet języka, by nazwać naturę tych zjawisk, posługuje się więc wizualizującymi metaforami pozwalającymi wyobrazić sobie, że zerojedynkowy kod zajmuje jakąś materialną czasoprzestrzeń. Z kolei czytanie informatycznego kodu źródłowego, mimo iż nie jest niemożliwe, tylko w niewielkim stopniu może przyczynić się do zrozumienia tego, co pojawia się w kulturowej warstwie cyfrowego projektu.

W dodatku środowisko mediów elektronicznych, choć zbudowane z pikseli, czyli mikropunktów, z których każdy może zostać wyodrębniony i obejrzany w powiększeniu ukazującym jego matematyczną naturę, projektuje odbiór będący zaprzeczeniem uwagi. Zbytnie przybliżenie powoduje rozmycie i zniekształcenie obrazu. Zatem, wbrew mikrologicznym nadziejom, jakie z nową sytuacją medialną zdaje się wiązać Nawarecki, można z dużym prawdopodobieństwem postawić tezę, że w Internecie nie ma miejsca dla literaturoznawców mikrologów. Lub inaczej: literaturoznawstwo - powtórzmy to raz jeszcze za Ritą Felski - musi ulec przekształceniu i nawiązać relację z innymi mediami oraz przyjrzeć się cechom specyficznych dla nich form artystycznych. Co więcej - mikropoetyka form digitalnych wymagać będzie od literaturoznawcy poszerzenia kompetencji, w tym o te z zakresu znajomości podstaw programów wykorzystywanych przy tworzeniu sztuki sieciowej i literackich hipertekstów ${ }^{31}$.

Intelekt - narzędzie mikrologa, dystansujące go do wirtualnych artefaktów - w środowisku literatury digitalnej staje się niezamierzenie sprzymierzeńcem konserwatywnego projektu powrotu do filozofii krytycznej. Tymczasem, zgodnie nie tylko z tezami Felski, ale też z ustaleniami badaczy zwrotu afektywnego, performatywnego czy somatycznego, rozumienie nie wiąże się tylko z refleksyjnością. Jeśli chcemy zrozumieć naturę nowych zjawisk kulturowych, postawę kontemplacyjną musimy zastąpić (lub uzupełnić) kategoriami afektywnymi: szoku, oczarowania, oszołomienia, zachwytu, odrazy, wstrętu. Przyjrzeć się swojej reakcji jako aktywnego uczestnika komunikacji. Badacz jest bowiem częścią układu, który próbuje scharakteryzować. Analizę prowadzi zawsze z perspektywy wewnętrznej i ta niemożność absolutnego zdystansowania wpisuje w jego sytuację warunki niepowodzenia działań zmierzających do ujednoznacznienia wniosków. O ile bowiem uwaga jako kulturowy konstrukt nadal podtrzymuje model spójnego i logicznego przedmiotu, nad którym panuje skoncentrowany i baczny obserwator, to w momencie, kiedy zamiast z przedmiotem mamy do czynienia $\mathrm{z}$ dynamicznym wydarzeniem, uważność przestaje być gwarancją zrozumienia.

\footnotetext{
${ }^{30}$ Por. A. Nawarecki, Mikrologia, genologia, miniatura, [w:] Miniatura i mikrologia, t. 1, s. 28.

${ }^{31}$ Warto pamiętać, że tworzenie literatury elektronicznej także od autorów wymaga wyposażenia w takie poszerzone kompetencje. Na stronie prezentującej techniczne zaplecze hipertekstów można przeczytać: „Młodym autorom, którzy rozpoczynają swoją drogę jako autorzy sztuki sieciowej, zalecamy [...] zgłębianie tajników HTML5, JavaScript, jQuery, Cocoa i Objective-C”. <http://techsty.art.pl/warsztaty/warsztaty/ warsztaty.htm> [dostęp: 10.02.2017].
} 
Jest tak nie tylko dlatego, że multimedia wymagają podzielnej uwagi, a to siłą rzeczy wiąże się ze spłyceniem percepcji i jej rozproszeniem. Przede wszystkim sama natura internetowych obiektów wyklucza odbiór refleksyjny, kontemplacyjny czy hermeneutyczny, nastawiony na bliski, intymny kontakt. Ich dynamika, wariabilizm, płynność i momentalność sprawiają, że albo dajemy się nieść wrażeniom, zanurzając się w tym, co oferuje interaktywne medium (co wcale nie jest proste - zgodnie z opisaną wcześniej autorefleksyjną samoświadomością badacza), albo postąpimy wbrew ich naturze: zatrzymamy obraz i będziemy go poddawać mikrologicznej analizie, badając np. screen po screenie (co zresztą technicznie nie zawsze jest możliwe). Wtedy jednak, skupieni na ustatycznionym detalu, tracimy z oczu to, co wydaje się warunkiem zrozumienia kulturowej zmiany: nowy typ doświadczenia estetycznego, budowanego na błyskawicznych, krótkotrwałych i ulotnych bodźcach mających działać wyłącznie (lub przede wszystkim) na sferę sensualną i emocjonalną. Tę zaś z powodzeniem może badać nowa mikroestetyka projektowana przez Ritę Felski, domagającą się otwarcia granic literaturoznawstwa na inne media. Przy czym metoda ta na razie pozostaje w sferze planów, bo dostępne dziś realizacje e-literatury oraz multimedialne przetworzenia sztuki słowa w rzeczywistości wirtualnej w zdecydowanie większym stopniu angażują krytyczne myślenie, aniżeli emocje. Wymuszając interaktywny współudział w tworzeniu jednorazowego artefaktu, stawiają badacza w potrójnej roli: twórcy, uczestnika i komentatora. To zaś po raz kolejny redefiniuje jego możliwości poznawcze ${ }^{32}$.

Warto cały czas mieć na względzie, że uwaga adaptuje się do nowych uwarunkowań technologicznych. Każde medium strukturyzuje nasze doświadczenie percepcyjne. Ekran jest dzisiaj głównym narzędziem zapośredniczającym kontakt odbiorcy z rzeczywistością zewnętrzną oraz tekstami kultury: zarówno tej werbalnej, jak i audiowizualnej. Jego właściwością jest rozpraszanie uwagi. Jeśli problemem od czasów Kanta była transcendentalna synteza pola poznania, które było zawsze cząstkowe i fragmentaryczne, dziś mówimy o całkowitej dezintegracji percepcji. Pożegnaliśmy się na dobre $\mathrm{z}$ marzeniem o syntezie. I właśnie to antysystemowe, zdekomponowane postrzeganie stanowi żyzne podłoże dla badań mikropoetologicznych w obrębie literaturoznawstwa. Są one, przynajmniej w pewnej mierze, wyrazem tęsknoty za utraconą wskutek wielkich historycznych i technologicznych procesów głębią, wagą i sensownością najbliższego świata. Jednocześnie mikropoetyka napotyka na drodze do swego przedmiotu zasadniczą trudność, o której przekonująco pisze Crary: jesteśmy dziś podmiotami niezdolnymi do długotrwałej koncentracji uwagi niezbędnej do tego, by móc na stałe ulokować badany obiekt w porządku uważności.

Zakłócona percepcja była wyznacznikiem nowoczesnej podmiotowości u Georga Simmela, Waltera Benjamina, Siegfrieda Kracauera, Theodora Adorno ${ }^{33}$. Socjologowie ci uważali, że rozproszenie i dekoncentracja to efekt nieodwracalnych zmian w kulturze. Crary natomiast pokazuje, że rozproszenie i koncentracja to continuum, a przejście od skupienia do dekoncentracji następuje stopniowo i niepostrzeżenie ${ }^{34}$. Jeśli przyjmiemy za Hannah Arendt, że

\footnotetext{
${ }^{32}$ Problem statusu badań nad zjawiskami interaktywnych, hipertekstowych i/lub multimedialnych obiektów digitalnych pomijam tu ze względu na ich złożoność i niewielki związek z tematem artykułu. Intuicja podpowiada mi jednak, że mikropoetyka nie jest w stanie sprostać opisowi zjawisk, o których tutaj mowa.

${ }^{33}$ Szerzej na ten temat patrz: J. Crary, Zawieszenia percepcji..., s. 70.

${ }^{34}$ Tamże, s. 73.
} 
w naszej kulturze nastąpił rozkład kontemplacji ${ }^{35}$, to kulturowe skutki tych zmian w postaci upadku wielkich narracji, rozpadu całościowej wizji świata i stałej dezintegracji jaźni są tylko konsekwencjami wielkich procesów trwających od kilkuset lat.

W tej sytuacji mikrologia okazuje się remedium na zmiany zachodzące w kulturze. Trochę niczym relikt wrażliwości historycznej, która wiązała się z filozofią nowoczesnego, w założeniach zintegrowanego i autonomicznego podmiotu, próbuje przeciwstawić się zjawiskom, które grają rolę rozpraszaczy i wymagają od nas raczej wielozadaniowości i podzielności uwagi, aniżeli skupienia na jednym elemencie.

Nieco podobne, bo osadzone na fundamencie refleksji filozoficznej, ujęcie problemu mikrologii zaproponował Paweł Jędrzejko ${ }^{36}$. Autor, dając wyraz swemu przywiązaniu do tradycyjnego, autonomicznego charakteru literaturoznawstwa, optuje jednakże za unaukowieniem mikrologii. Uznaje ją za jasno zdefiniowaną perspektywę badawczą, traktując jako pomost między Gadamerowską hermeneutyką i współczesną krytyką świadomości. Mikroanaliza (i mikrodekonstrukcja) to w jego ujęciu etapy działania hermeneutycznego koła. Mikrologia miałaby być dziedziną z pogranicza poetyki opisowej i historycznej, „zajmującą się szczegółem literackim, jego «życiem» i przemianami w tekście lub w tekstach, koncentrującą się na analizie roli i funkcji detalu w kształtowaniu immanentnej poetyki dzieła, lub też - w ujęciu diachronicznym - rozważającą szczegół jako indykator historycznych zmian poetyki w makroskali”37. Byłaby więc postawą dość tradycyjnego rozbioru tekstu. Jednocześnie jednak - i to czyni głos Jędrzejki interesującym dla niniejszego wywodu - mikrologia definiowana jest przez niego jako stanowisko filozoficzne. Zainteresowanie szczegółem jako „miejscem, gdzie splatają się z sobą współczesna krytyka tematyczna i tradycyjna hermeneutyka; to, co znakowe, z tym, co bytowe" ${ }^{38}$ prowadzi badacza do konkluzji, że „mikrologię, wynikłą z niepokoju post-Derridiańskiego pokolenia, powołała do życia rozbieżność między bytem a dyskursem: łącząc - przez emocję - bytowość szczegółu i jego znakowość, mikrologia uprawnia interpretację bona fide, opartą na filologicznej rzetelności «uczenia się języka» dzieła i epoki" ${ }^{39}$.

Owa idea bona fide; dobrej wiary, z jaką dokonuje się rozbioru dzieła, którą podziela znaczna część autorów prac, zamieszczonych w kolejnych tomach redagowanej przez Aleksandra Nawareckiego Mikrologii literackiej, przesłania jednak to, co zdaje się istotnym novum i szansą owej przywołanej przez badacza „post-derridiańskiej” perspektywy: jej kruchość, prowizoryczność i - przede wszystkim - immanentny opór wobec takich fundamentalnych kategorii jak ,język dzieła i epoki”, przeciwko których uzurpacyjnym uproszczeniom, podobnie jak przeciwko wszelkim uogólnieniom, pewnikom i ustaleniom, mikropoetyka występuje w praktyce lekturowej. Bo też mikropoetyka jest przede wszystkim praktyką czytania. Praktyką, powtórzmy, nie teorią. Mikropoetyka wnika w drobiny tekstowe, ale też w szczeliny

\footnotetext{
${ }^{35}$ Por. H. Arendt, Kondycja ludzka, przeł. A. Łagodzka, Warszawa 2000.

${ }^{36}$ P. Jędrzejko, Oscylacje literackie, czyli od Gadamera do mikrologicznej krytyki świadomości, [w:] Mikrologia, t. 2.

${ }^{37}$ Tamże, s. 29.

${ }^{38}$ Tamże, s. 56.

${ }^{39}$ Tamże, s. 55-56.
} 
pomiędzy nimi, próbuje zgłębić to, co niewypowiedziane i niewypowiadalne. Nie jest więc wyłącznie sztuką analizy, lecz, przede wszystkim, interpretacji.

W obszernym eseju Czarna mikrologia ${ }^{40}$ otwierającym kolejną, czwartą już publikację śląskich badaczy poświęconą rozmaitym kontekstom, rozumieniom i użyciom kategorii małości w badaniach literackich, Nawarecki również nie na metodzie się skupia, lecz na mikrologicznej wrażliwości i estetyce. Jest ona w jego ujęciu estetyką rzeczy drobnych, znikomych, estetyką znikającego świata melancholika, kolekcjonera drobin i rzeczy pozornie bezużytecznych, ważnych wyłącznie w perspektywie indywidualnej, jednorazowej egzystencji. Podejście mikrologiczne reprezentuje ten, kto, jak Adorno w „Refleksjach z poharatanego życia” sporządzonych z perspektywy intelektualisty i Żyda, który przeżył Zagładę swojego narodu, próbuje przesylabizować własne Minima Moralia ${ }^{41}$. To perspektywa tego, kogo własne doświadczenia i pamięć zakotwiczają w przeszłości i kto na współczesność spogląda jako na usypisko fragmentów i ruin, poświadczających nietrwałość świata, kruchość i przemijalność rzeczy. Sygnatura melancholii znaczy zatem warsztat mikrologa, albowiem to, co małe, nie tylko bywa ulotne, lecz także często przeoczane i dopiero gdy bezpowrotnie zostanie utracone, staje się przedmiotem czułej adoracji. Jego byt jest czysto hipotetyczny, potencjalny, dopóki nie wydobędzie go na jaw przenikliwe spojrzenie lub myśl mikrologa, który jednakowoż nie tylko zmysłom ufa, lecz posługuje się wszystkimi dostępnymi mu precyzyjnymi narzędziami rozbioru i analizy, pozwalającymi nazwać i uwierzytelnić to, co dotychczas znajdowało się poza horyzontem istnienia i rozumienia.

Poetyka mikrologiczna jest po trosze poetyką metafizyczną, a zarazem postsekularną, ufundowaną na doświadczeniu utraty, jak również wiary w wartość tego, czego nie da się wyrazić wprost, pochwycić w rygor składni i logicznej argumentacji. Jest w znacznej mierze oparta na przekonaniu, że to, co istotne, ujawnia się w przebłyskach, ulotnych mgnieniach, chwilach, którym uwaga czytelnika nadaje pełny kształt. Uważność i skupienie mają dać odpór percepcji poddanej działaniu masowych technologii medialnych, którą już w latach trzydziestych XX wieku Benjamin opisywał jako przebiegającą w stanie dystrakcji ${ }^{42}$.

W istocie nadmiar bodźców, docierających do nas, sprawia, że coraz mniej jesteśmy w stanie dostrzec, coraz powierzchowniej odbieramy rzeczy i stany, coraz mniej wrażliwi jesteśmy na docierające do nas sygnały. Mikropoetyka byłaby więc remedium na chorobę ponowoczesnej zdezintegrowanej podmiotowości. Remedium aplikowanym z premedytacją, wbrew wymuszanym przez współczesny usieciowiony świat: podzielności uwagi, wielozadaniowości, szybkości podejmowania decyzji i działań ${ }^{43}$. Mikropoetyka zatrzymuje czas, zamraża go w uważnym spojrzeniu

\footnotetext{
${ }^{40}$ A. Nawarecki, Czarna mikrologia, [w:] Skala mikro w badaniach literackich, s. 9-24.

${ }^{41}$ T. Adorno, Minima Moralia. Refleksje z poharatanego życia, przekł. i przypisy M. Łukasiewicz, posłowie M. J. Siemek, wyd. 2, Kraków 2009.

${ }^{42}$ W. Benjamin, Dzieło sztuki w epoce możliwości jego technicznej reprodukcji, [w:] Anioł historii: eseje, szkice, fragmenty, red. H. Orłowski, przeł. K. Krzemieniowa i in., Poznań 1996, s. 171-172.

${ }^{43}$ Właściwości percepcji w usieciowionym środowisku informacyjnym interesująco opisuje Karol Piekarski w swojej rozprawie doktorskiej. Por. K. Piekarski, „Ekonomia percepcji. Mechanizmy selekcjonowania informacji w Internecie", rozprawa doktorska napisana pod kierunkiem prof. Tadeusza Miczki, Katowice 2014 , <http://sbc.katowice.pl/Content/126980/doktorat3505.pdf> [dostęp: 12.02.2017]. Tu zwłaszcza rozdziały poświęcone przemianom percepcji oraz historycznym kontekstom zjawiska przeciążenia informacyjnego.
} 
podążającym wgłąb. Za nic ma współczesną estetykę znikania ${ }^{44}$, która w pędzie obrazów i rzeczy każdy szczegół przekształca w rozmywającą się w oddaleniu smugę. To postawa melancholika, który tęsknie wypatruje wypełnienia braku, odczuwanego dotkliwie wśród nieuważnych, żyjących w pośpiechu ludzi i migoczących obrazów pozbawionych głębi.

W upodobaniu do skali mikro ujawnia się chęć przeciwstawienia się wielkim, globalizacyjnym, uogólniającym i ujednolicającym procesom. Jest w nim pragnienie ocalenia tego, co niepowtarzalne, co jedyne w swoim rodzaju i własne, bo lęk przez nicością, anonimowością, jednolitością drąży współczesność. Szukamy zatem nań lekarstwa na naszą miarę: w afirmacji detalu, drobiazgu, w ulotnym doznaniu czegoś prawdziwego. Tylko one, niezauważone przez postronne oko i wrażliwość, dają nam poczucie wyjątkowości.

Mikropoetyka jako ucieczka w małość, w detal nie powinna zakładać jednak, że skoro nie da się ogarnąć całości, to można wyodrębnić przynajmniej najmniejszą, niepodzielną cząstkę, której można się przyjrzeć. Mikrocząstka literacka nie jest cząstką elementarną jak kwant w fizyce czy punkt w matematyce. Po krytycznym doświadczeniu dekonstrukcji ani empiryczne próby wyczerpania bogactwa literackiego przedmiotu, ani ontologiczny charakter tegoż przedmiotu, który stanowi rozumiane po Derridiańsku pole wolnej gry, nie pozwalają na osiągnięcie ostatecznego celu. Postawa mikrologa to właśnie efekt uświadomienia sobie tego, że nie da się posiąść całej wiedzy o obiekcie badań, wyczerpać jego opisu, rozpisać wszystkich możliwych wersji interpretacji.

Dlatego mikropoetyka nie jest metodą innowacyjną, jak sugeruje omawiająca recepcję śląskiej mikrologii Ewelina Suszek ${ }^{45}$, nie jest też modą metodologiczną. Stanowi raczej reakcję na utracone marzenia nowoczesnego literaturoznawstwa, których symbolem był strukturalistyczny projekt interpretacji jako hipotezy ukrytej całości. Jest też mikropoetyka świadomym, bogatszym o wszystkie zdobyte przez wieki doświadczenia, powrotem do źródeł - do skromnych rzemieślniczych zadań filologa, który na gruzach wielkich systemów cierpliwie odbudowuje swój maleńki prowizoryczny warsztat, dający mu kruche poczucie rzetelności i namiastkę profesjonalizmu.

\footnotetext{
${ }^{44}$ Określenie „estetyka znikania” zapożyczam od Paula Virilio (Esteique de la disparation, Paris 1980), który w swoich pracach wielokrotnie podkreślał kluczową dla postępu oraz strukturyzującą społeczeństwo rolę prędkości. Zwłaszcza w odniesieniu do współczesnej cywilizacji można mówić o ogromnym przyspieszeniu, co unaoczniło pojawienie się kina. Sztuka kinematograficzna stanowi, zdaniem Virilio, kwintesencję zmiany, ponieważ to w niej, jak referuje Krystyna Wilkoszewska, „nastąpiło przejście od estetyki materialnych nosicieli rzeczy i dzieł ku estetyce znikania, bowiem w technice filmowej rzeczy są tym bardziej obecne im szybciej się ulatniają" (K. Wilkoszewska, Paula Virilio filozofia prędkości i estetyka znikania, „Kultura Współczesna” 1993, nr 1, s. 110).

${ }^{45}$ E. Suszek, Moda na małe? Innowacyjność śląskiej mikrologii literackiej, „Postscriptum Polonistyczne” 2016, nr 1(17), s. 179-191.
} 


\title{
SEOWA KLUCZOWE:
}

BADANIA LITERACKIE

p o n o w o c z e s no ść

\begin{abstract}
AbstrakT:
Artykuł jest próbą umiejscowienia mikropoetyki na mapie współczesnych zjawisk kulturowych oraz w kontekście innych dziedzin nauki. Autorka traktuje mikropoetykę jako subiektywną, nastawioną na szczegółową analizę detalu quasi-metodę literaturoznawczych badań. Wskazuje na cechy łączące ją z tradycyjnymi badaniami filologicznymi, a także na to, co stanowi jej novum: jednorazowość strategii lekturowej, dostosowywanej do przedmiotu analizy, zindywidualizowane podejście do dzieła oraz samoświadomość badacza mikrologa, zdystansowanego wobec własnych sądów i świadomego ich sytuacyjności. Głównym wyznacznikiem mikrologii staje się w tym ujęciu uważność, omawiana tu również jako kategoria umocowana historycznie.
\end{abstract}




\section{mikropoetyka}

\section{analiza}

\section{uważność}

\section{NOtA O AUTORzE:}

Elżbieta Winiecka - dr hab., adiunkt w Zakładzie Literatury i Kultury Nowoczesnej na Uniwersytecie im. Adama Mickiewicza w Poznaniu. Zajmuje się literaturą nowoczesną w kontekstach kulturowych i filozoficznych. Bada relacje między techniką i sztuką literacką, zwłaszcza w Internecie, interesują ją zjawiska remediacji i intermedialności literatury. Autorka książek: Białoszewski sylleptyczny (Poznań 2006), Z wnętrza dystansu. Leśmian - Karpowicz - Białoszewski - Miłobędzka (Poznań 2012), współredaktorka książek Kres logocentryzmu i jego kulturowe konsekwencje (Poznań 2009), Pochwała uważności. Studia o twórczości Julii Hartwig (Poznań 2015), współautorka Ćwiczeń z poetyki (red. A. Gajewska, T. Mizerkiewicz, Warszawa 2006) oraz Kompozycji i genologii (red. A. Gajewska, Poznań 2009). Redaktorka „Poznańskich Studiów Polonistycznych. Serii Literackiej”. 